of Western Europe. But not for long. The niceties of reunification apart, West Germany's government and business community seem determined that there shall be enough investment in East German industry to effect a rapid transformation of its industry - and to persuade East German families to stay where they are.

Meanwhile, this week's excitement notwithstanding, reunification is not yet a formality. One obviously outstanding question is that of security in Central Europe. Mr Mikhail Gorbachev's critics in Moscow, already uneasy that a buffer state should have elected to join the other side, are unlikely also to let the Soviet Union comply with Chancellor Helmut Kohl's assumption that a united Germany will simply be a larger member of the North Atlantic Treaty Organization (NATO). Yet the status quo, with hostile armies and missiles facing each other in the two parts of Germany, is plainly a nonsense. Willy-nilly, there will have to be a bargain, probably one in which nuclear missiles and foreign armies are removed. Is the West, or even Germany, ready for that?

The other complication is West Germany's membership of the European Communities. Even if the federal constitution allows eastern German-speaking states simply to accede, East Germany cannot quickly comply with community directives on matters such as water quality, highway safety and public subsidy of industrial production. But derogation of the rules in favour of what is now East Germany will set up a clamour by most other member states for exemption from what they regard as onerous obligations. It is not for nothing that $\mathrm{M}$. Jacques Calvet, president of the French car-maker Peugeot, said at the weekend that the plan to create a true free market by 1992 had best be postponed until the uncertainties of German reunification have been settled. But that could mean postponement for good.

What can be done to overcome these difficulties? It would be easier if there were a coherent view of what the future of Europe might be like, but only Mr Vaclav Havel, now the president of Czechoslovakia, will chance his arm on that. He would dissolve NATO and the Warsaw Pact, and extend the European Communities to the East. A better bet would be that the two alliances should be merged, perhaps along the lines of the treaty that established Western European Union in 1948 (the crucial amendments to which were signed in 1954) and which, among other things, limits the freedom of acceding states to make nuclear weapons and long-range missiles. The same treaty requires its members to encourage the "progressive integration" of Europe, best accomplished in present circumstances by cultural means. Universities and grant-making research organizations have a larger role to play than they may think.

Outside Germany, East or West, politicians have been quick to wring their hands over the prospect of reunification, but have so far said very little about the ways in which Central Europe might accomodate the past year's dramatic changes in the East. What else, but reunification, can they expect?

\section{Market museums}

The earliest fossil lizard has caught complacent British museums unawares.

MR Stan Wood, the freelance Scottish fossil-hunter, may have done more for British palaeontology than he knows - and more than British museums are yet willing to acknowledge. A few months ago, Mr Wood announced his discovery of the earliest known reptile, fondly known as 'Lizzie', and arranged to sell it to the Museum für Naturkunde at Stuttgart. Now, the National Museums of Scotland are scratching around to meet Stuttgart's price of $£ 207,000$, when British heritage legislation would give it the right to stand in Stuttgart's place. Inevitably, there are those who grumble that more patriotic fossil-hunters would not have put a British museum in that ignominious position. The truth is otherwise.

First, Wood has a clear legal title to his fossil and a right to sell it to whoever he chooses. Second, British museums should reflect that one of them would have had Wood's specimen for nothing if only they had persuaded him to work as a professional curator (which he once did). But, scandalously, there are no jobs. Last year, the Biology Curators' Group complained that 34 research posts have been axed from British museums since 1984, and that many more are vacant. And that is not surprising. A recent advertisement fiom the Liverpool Museum offered a top salary of $£ 9,646$ for a qualified biological curator. It is no wonder that only 33 natural history museums in Britain have qualified technicians to maintain their collections.

Why, it may be asked, when British museums cannot properly look after what they have, should they seek funds to match Stuttgart's bid? Or, to turn the argument around, if they had access to $£ 207,000$ without strings, would the purchase of the earliest fossilized reptile be the best use of the money? Chauvinism apart, complacent museum policies have conspired with a decade of public parsimony towards research to rob many institutions of a proper regard for their obligations.

Museums are also, of course, important means by which a wider public can share the fruits of professional scholarship, ultimately to the benefit of the professions concerned. The danger, especially at the British institutions forced by circumstances to levy admission charges, is that marketing takes charge. In Britain, the Natural History Museum (in London) is controversially in the van of those who regard their public image as a safeguard; its corporate plan, now imminent, will be scrutinized for signs that adequate salaries and staffing levels are being given the priority they deserve. Even in the marketplace museum, curatorship is not just a monetary sink. The museum that had employed Stan Wood would now have the earliest fossil reptile in a showcase at no cost - and would probably have earned $£ 207,000$ extra in admission fees.

NATURE · VOL 344 22 MARCH 1990 